\title{
Invader Potential and Population Structure of Non-Native Fish Species, Cyprinus carpio with Respect of Climate from the Vindhya Region, India
} Amitabh Chandra D, Priyanka $M$ and Ashish $\mathrm{T}$

Regional Centre, ICAR-Central Inland Fisheries Research Institute, Allahabad, India

"Corresponding author: Amitabh Chandra D, Regional Centre, ICAR-Central Inland Fisheries Research Institute, 24 Panna Lal Road, Allahabad-211002, India, Tel: +033-25920177; E-mail: saajjjan@rediffmail.com

Received date: Oct 31, 2016; Accepted date: Dec 13, 2016; Published date: Dec 26, 2016

Copyright: (c) 2016 Amitabh Chandra D, et al. This is an open-access article distributed under the terms of the Creative Commons Attribution License, which permits unrestricted use, distribution, and reproduction in any medium, provided the original author and source are credited.

\begin{abstract}
Cyprinus carpio is a non-native fish species in the India. Studies were undertaken during January 2015 to February 2016 from the Ken river (Vindhyan region), India. 505 fish specimens (247 males and 258 females) were examined of Cyprinus carpio for determination of population structure. Age composition ranged from $0+$ to $10+$ years with powerfully invaded in the river. The $1+$ and $2+$ age group was most exploited $(20.65 \%$ each) population in case of male while in case of female $2+$ age group was most exploited with $21.70 \%$. After $2+$ age group exploitation was decreased with increasing of the age of fishes. Male population was dominated in $0+, 1+$ and $3+$ age groups compared to female fishes. In stock, female population was more exploited than male. The $9+$ and $10+$ age groups of fishes were shared very minute proportion.
\end{abstract}

Keywords: Invader potential; Population structure; Vindhyan region; Ken river; Age group; Cyprinus carpio

\section{Introduction}

Cyprinus carpio, commonly known as common carp, is a nonnative major carp which is widely distributed in the inland waters of India [1]. C. carpio has a long history of domestication [2,3]. It is the only fish which has perhaps a globally distribution since the current century $[4,5]$. It is a hardy fish that is well suited for aquaculture and fast growing fish [6]. It dwells in lower reaches of rivers and shallow confined waters with slow flowing or standing water and soft bottom sediments $[7,8]$. Common carp are frequently cultured and are of great commercial value as a fish for food, both over their native and introduced range [1,9]. It forms most productive fishery (riverine) in Central India with Oreochromis niloticus [10-14]. Their ability to thrive in new water bodies has caused many ecosystem management problems [15-17]. Common carp makes the most acceptable warmwater fish for commercial fish culture [15]. It can be cultivated under tropical condition up to an altitude of $1000 \mathrm{~m}$ above sea level. The common carp is cultured alone or along with Indian major carps [2].

The present study was thus undertaken to estimate the invader potential and population structure of $C$. carpio with respect of climate from the Ken river, India. This study will help in formulation the fishery management policies of C. carpio and Indian major carp in the Ken river (Vindhyan region).

\section{Materials and Methods}

The fish samples were collected during months of January 2015 to February 2016 from the Ken river. The Ken river is a major right bank tributary of the Yamuna river, India. For collection of data, Banda and Chilla fish markets were visited. Fishes were fished by a variety of methods including drag netting, cast netting, gill netting and hook and line. Samples of scales from 505 specimens, total length ranging between 10.7-76.6 $\mathrm{cm}$ were examined for age determination of the fishes.

Total length was measured from the tip of caudal fin to snout of the fish. The key scales were collected from the region just below the dorsal fin (3-4 rows) and above the lateral line and were thoroughly washed in tap water until all extra matter got completely removed and mounted intact in between two glass plates. The ring formation was determined according to the criterion suggested $[6,7,18,19]$. Almost all the annuli, except the one, appeared as light relatively transparent bands, concentrically arranged around the whole of the anterior sculptured part of the scales. The recording of age was done with the help of scales collected. Number of fishes in each age group was converted into percentage to obtain population structure.

\section{Results and Discussion}

Age composition varied from $0+$ to $10+$ years from the Ken river, India. Ecological condition of the Ken river is very disturbed due to sand mining. Poor water quality of the river also helpful for powerfully invaded C. carpio in the river. Population structure was determined with the help of males and females. The 505 fish specimens $(247$ males and 258 females) were examined of $C$. carpio for determination of population structure.

The 2+ age group was most exploited population and this age group more attracted to fishermen for exploitation. The $2+$ age group also had good price value for these region consumers. After 2+ age group exploitation was decreased with increase of the age of fishes. Male population was dominated in $0+, 1+$ and $3+$ age groups compared to female from the Ken river (Table 1). In stock, female population was more exploited than male. The $9+$ and $10+$ age groups of fishes were shared very minute proportion.

The $11+$ age group of $C$. carpio was recorded from the Ganga river with small proportion of higher age group in the stock [7]. The poor water quality of the Ken river is most suitable for C. carpio at Banda and Chilla sites. 
Citation: Amitabh Chandra D, Priyanka M, Ashish T (2016) Invader Potential and Population Structure of Non-Native Fish Species, Cyprinus carpio with Respect of Climate from the Vindhya Region, India. J Climatol Weather Forecasting 4: 186. doi:10.4172/2332-2594.1000186

Page 2 of 2

\begin{tabular}{|l|l|l|l|l|}
\hline $\begin{array}{l}\text { Age } \\
\text { classes }\end{array}$ & Male & Percentage & Female & Percentage \\
\hline $0+$ & 29 & 11.74 & 27 & 10.46 \\
\hline $1+$ & 51 & 20.65 & 49 & 18.99 \\
\hline $2+$ & 51 & 20.65 & 56 & 21.70 \\
\hline $3+$ & 44 & 17.81 & 44 & 17.05 \\
\hline $4+$ & 26 & 10.53 & 29 & 11.24 \\
\hline $5+$ & 16 & 6.48 & 17 & 6.58 \\
\hline $6+$ & 11 & 4.45 & 12 & 4.65 \\
\hline $7+$ & 08 & 3.24 & 10 & 3.87 \\
\hline $8+$ & 06 & 2.43 & 07 & 2.71 \\
\hline $9+$ & 03 & 1.21 & 04 & 1.55 \\
\hline $10+$ & 02 & 0.81 & 03 & 1.16 \\
\hline Stock & 247 & - & 258 & - \\
\hline
\end{tabular}

6. Dwivedi AC, Mayank P (2013) Studies on the age, growth pattern and sex ratio of Cyprinus carpio var. communis from the largest tributary of the Ganga river, India. J Kalash Sci, pp: 21-27.

7. Pathak RK, Gopesh A, Dwivedi AC (2011). Age composition, growth rate and age pyramid of an exotic fish species, Cyprinus carpio var. communis from the Ganga river at Allahabad, India. Natl Acad Sci Lett 34: 223-228.

8. Dwivedi AC, Mayank P, Tiwari A (2016) The River as transformed by human activities: the rise of the invader potential of Cyprinus carpio and Oreochromis niloticus from the Yamuna River, India. J Earth Sci Clim Change 7: 361 .

9. Britton JR, Chucherousset J, Davies GD, Godard MJ, Copp GH (2010) Non-native fishes and climate change: predicting species responses to warming temperatures in a temperate region. Freshwater Biol 55: 1130-1141.

10. Mayank P, Kumar A, Dwivedi AC (2011) Alien fish species Oreochromis niloticus (Linnaeus, 1757) as a powerful invader in the lower stretch of the Yamuna River. Bioved 22: 65-71.

11. Dwivedi AC, Jha DN (2013) Population structure of alien fish species, Oreochromis niloticus (Linnaeus, 1757) from the middle stretch of the Ganga river, India. J Kalash Sci 1: 157-161.

12. Mayank P, Dwivedi AC (2015) Biology of Cirrhinus mrigala and Oreochromis niloticus. LAP LAMBERT Academic Publishing GmbH \& Co. KG, Dudweiler Landstr. 99, 66123 Saarbrucken, Germany, p: 188.

Table 1: Population structure of Cyprinus carpio from the Ken river, India.

The DO level was recorded in the Ken River below $6 \mathrm{mg} / \mathrm{l}$ throughout year. The Indian riverine sector (especially central India) presently dense by $C$. carpio due to poor water quality [1]. Population structure of the large size fishes are mostly varying from habitat to habitat and region to region [20].

It may be concluded that the $C$. carpio well stable from the Yamuna river. The age group $2+$ is most dominated in the river.

\section{References}

1. Dwivedi AC, Mishra AS, Mayank P, Tiwari A (2016) Persistence and structure of the fish assemblage from the Ganga river (Kanpur to Varanasi section), India. J Geogr Nat Disast 6: 159.

2. Dwivedi AC, Jha DN, Mayank P (2014) Food security, livelihood and non-native fish species: status, trends and future perspectives. J Kalash Sci 2: 41-46.

3. Pathak RK, Gopesh A, Dwivedi AC (2015) Invasion potential and biology of Cyprinus carpio (Common carp) LAP LAMBERT Academic Publishing GmbH \& Co. KG, Dudweiler Landstr. 99, 66123 Saarbrucken.

4. Vilizzi L, Tarkan AS, Copp GH (2015) Experimental evidence from causal criteria analysis for the effects of Common carp Cyprinus carpio on freshwater ecosystems: A global perspective. Rev Fisher Sci Aqua 23: 253-290.

5. Tiwari A, Dwivedi AC (2014) Assessment of heavy metals bioaccumulation in alien fish species Cyprinus carpio from the Gomti river, India. Euro J Exp Biol 4: 112-117.

13. Dwivedi AC, Tiwari A, Mayank P (2015) Seasonal determination of heavy metals in muscle, gill and liver tissues of Nile tilapia, Oreochromis niloticus (Linnaeus, 1758) from the tributary of the Ganga River, India. Zool Ecol 25: 166-171.

14. Dwivedi AC, Mayank P, Imran S (2016) Reproductive structure of invading fish, Oreochromis niloticus (Linnaeus, 1757) in respect of climate from the Yamuna river, India. J Climatol Weather Forecasting 4: 164.

15. Dwivedi AC, Tewari NP, Singh KR (2004) Present structure of capture and culture fishery of the Faizabad District (U.P.). Bioved 15: 95-98.

16. Dwivedi AC, Mayank P, Masud S, Khan S (2009) An investigation of the population status and age pyramid of Cyprinus carpio var. communis from the Yamuna river at Allahabad. Asian J Anim Sci 4: 98-101.

17. Tiwari A, Dwivedi AC, Mayank P (2016) Time scale changes in the water quality of the Ganga River, India and estimation of suitability for exotic and hardy fishes. Hydrol Curr Res 7: 254.

18. Bagenal T, Tesch F (1978) Age and growth. In: T. Bagenal T (ed.) Methods for Assessment of Fish Production in Fresh Waters. Blackwell Scientific Publication Oxford (3rd Edn.), pp: 101-136.

19. Mayank P, Tyagi RK, Dwivedi AC (2015). Studies on age, growth and age composition of commercially important fish species, Cirrhinus mrigala (Hamilton, 1822) from the tributary of the Ganga river, India. Eur J Exp Biol 5: 16-21.

20. Dwivedi AC, Mayank P (2016) Population structure of Indian major carp species, Cirrhinus mrigala (Hamilton, 1822) from the Ganga river, India. J Kalash Sci 4: 55-58. 